\title{
Survival analysis and cut-off point to estimate the shelf life of refrigerated fish burgers
}

\author{
Caroline MARQUES ${ }^{1}$, Carla Cristina LISE ${ }^{1}$, Vanderlei Aparecido de LIMA ${ }^{1}$, Marina Leite Mitterer DALTOÉ ${ }^{1 *}$ (D)
}

\begin{abstract}
The consumption of fish in Brazil is below the world average. In order to change this scenario, considering the high nutritional value of this meat, one of the strategies is to turn fish into a convenient product, such as burgers. Since fish burgers are not yet established in the market, it requires investigation of the shelf life. To that end, survival analysis and cut-off point (COP) methodologies access the perception of consumers and trained panels. Thus, the objective of this study was to estimate the shelf life of grass carp burgers, by means of the survival analysis and cut-off point. A trained sensory panel and consumers evaluated the burgers during a refrigerated storage of 30 days. Simultaneously, the $\mathrm{pH}$ and the reactive substances of thiobarbituric acid (TBARS) were evaluated. The TBARS results corroborated rancidity observed both with exponential growth and with correlation coefficients above 0.98 . The survival analysis determined the end of the shelf life of the fish burgers after 21 days, with the COP technique indicating 17 days. Both methodologies were efficient in estimating the shelf life of the product analyzed, considering the lower result from COP adequate, since it establishes the value were the acceptability begins to decrease.
\end{abstract}

Keywords: storage; grass carp; rancid flavor; sensory; lipid oxidation.

Practical Application: Transforming the fish meat into a convenient product is a strategy to improve fish consumption, in an attempt to insert the fish intake habit. The refrigerated product facilitates its use including school meals. A refrigerated burger, vacuum packed, with more than 15 days of shelf life, microbiologically stable, using a non-usual nutritive fish species, is an important result to the research and development field.

\section{Introduction}

Brazilians consume $9.6 \mathrm{~kg}$ per capita/year of fish meat, a low consumption rate in contrast to the world average value of $19.2 \mathrm{~kg} /$ year (Food and Agriculture Organization, 2016). The limited consumption of freshwater fish in Brazil occurs due to cultural and economic factors. Additionally there is a limited availability and diversity of species and products based on this type of meat (Mitterer-Daltoé et al., 2012).

It is known that patterns of healthy diets that include fish consumption should be established in childhood (Donadini et al., 2013), thus, to improve the fish consumption, the Brazilian government has been applying public policies aimed at school meals. Inclusion of fish in school meals becomes an important strategy to encourage younger Brazilians to develop the habit of eating fish.

An interesting plan of fish insertion in infant feeding is the presentation in alternative forms such as nuggets (Mitterer Daltoé et al., 2017), hamburgers (Breda et al., 2017) and meat balls (Latorres et al., 2016). In addition, derivatives can be presented fresh, refrigerated and prepared by the own school cooks (Breda et al., 2017).

Nevertheless, the importance of developing fish derivatives goes beyond their inclusion in school meals. The high perishable nature of fish, regarding the $\mathrm{pH}$ value near to neutrality and the high water activity, favors bacterial growth (Comi et al., 2015) and causes the reduction of stability of the fresh meat to a few days when refrigerated and a few months when frozen.

These facts have combined to stimulate the production of ready-made seafood products (Sveinsdóttir et al., 2010; Vanitha et al., 2015), increasing the consumption, offering new forms of fish products, with larger shelf-life. At the same time, working with products not yet established on the market as fish burgers requires investigation of the shelf life and it depends on the interaction between consumer and product. To that end, there are several methods to determine the shelf life of foods.

For example, the survival analysis is a statistical method used in clinical, biological and sociological studies, which was inserted subsequently into the sensory analysis field with many applications in food products (Esmerino et al., 2015; Garitta et al., 2018; Giménez \& Ares, 2019). Within the survival analysis method, literature has demonstrated some different methods of applying it, such as the cut-off point (COP) method. It uses trained assessors and consumers to determine after exactly how many days the product is no longer good for consumption, creating a graph that relates the intensity of a critical descriptor (or defect) as a function of the storage time (Giménez et al., 2012; Hough \& Fiszman, 2005).

Both methodologies present different results when applied to the same product, showing the importance of investigating 
the two combined. The concrete importance of additional consumer tests within the survival analysis was also verified by Esmerino et al. (2015) when studying the petit suisse's shelf life. Although they have demonstrated that survival analysis and JAR scales have similar results, the results pointed some advantages in the survival method, as it is a consumer-friendly way to predict the optimum formulation and a practical method for researchers performing experimental sensory work in a simpler and cost effective way. This feasibility of applying innovative sensory methods based on consumers' perception has been emphasized in several recent studies (Belusso et al., 2016; Horita et al., 2017; Marques et al., 2019; Santos et al., 2015).

Examining the main possible defect in fish burger storage, the literature mentions the lipid oxidation as the primary deterioration process of fish quality and its products besides protein degradation (Cai et al., 2014; Fogaça \& Sant'Ana, 2007). It is perceived through strong smell and taste and decelerated with low temperature and modified atmospheres (Raisi, Ghorbani et al., 2015).

Moreover, the purpose of this study is to determine the shelf life of grass carp burgers vacuum packed, comparing the results from the survival analysis and the cut-off point methodology, employing the rancid flavor as the critical descriptor. Along with that, the $\mathrm{pH}$ and reactive substances of thiobarbituric acid (TBARS) will be accessed periodically throughout the storage time, to corroborate the rancidity profile.

\section{Materials and methods}

\subsection{Raw material}

In order to overcome the limited availability of species and to encourage the inclusion of other potential cultures of freshwater fish, the grass carp was applied in the present study. This species has a fast growth rate, easy cultivation and high feed efficiency ratio (Tokur et al., 2006), whose production is favored under the conditions found in the southwest of Parana State, Brazil.

The fish fillets of grass carp were purchased through a project partnership with a local fish farmer in Pato Branco, Parana State, Brazil. After capture, the fish were percussive stunned on the head, slaughtered (marrow section followed by bleeding), weighed, skinned, gutted and filleted for transport in styrofoam boxes with ice.

\subsection{Fish burger manufacture}

The burgers were prepared, 18 hours after slaughtering, in the Food Technology Lab at UTFPR (N008) according to the formulation described by (Marques et al., 2017). The fillets were removed from the freezer, ground in a food processor, basic washed, mixed in a sanitized bowl (Figure 1a), shaped into 125g units and sealed in a portable vacuum machine (Figure 1b). Nylon merged with polyethylene packages were applied, showing high barrier properties, along with vacuum sealing, combination evaluated and approved for the 28-day storage of fish burgers (Del Nobile et al., 2009).

The basic washing removes the sarcoplasmic proteins and pigments, reduces the fishy odor of the pulp and brightens the meat. The nitrogen compounds were removed using $0.1 \%$ sodium bicarbonate $\left(\mathrm{NaHCO}_{3}\right)$ followed by two cycles of distilled water and ending with $0.3 \%$ sodium chloride $(\mathrm{NaCl})$. Each wash cycle took two minutes at temperatures between $5-7^{\circ} \mathrm{C}$. After each washing cycle, the pulps were separated by centrifugation (Furlan et al., 2009).

\subsection{Sensory evaluation}

\section{Survival analysis}

After the preparation of the burgers they were stored under refrigeration, and samples removed for the sensory analysis after 1, 7, 14, 17, 21, 23, 25 and 30 days (based on 22-days of shelf life found by (Del Nobile et al., 2009). These samples were immediately frozen to stop any reactions $\left(-18^{\circ} \mathrm{C}\right)$. After completing the storage period ( 30 days), the samples were thawed.

The sensory analysis was carried out using 80 assessors (consumers) who evaluated the overall acceptability. The panels consisted of students, teachers, researchers and employees of the UTFPR - Pato Branco. Moreover, the Ethics Committee - CAAE number 48687815.0.0000.5547, approved the study.
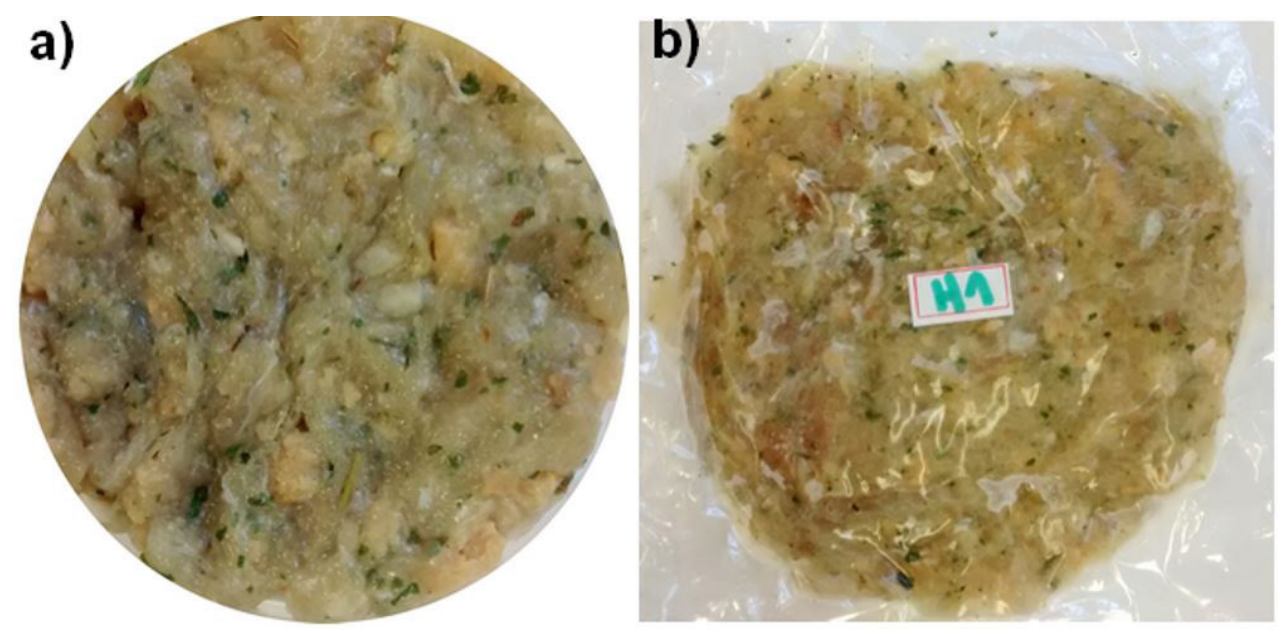

Figure 1. Grass carp burger (a) unpacked and (b) vacuum sealed (from day 1 of storage). 
After thawed the burgers were grilled to serve the assessors and cut into uniform sizes of approximately $1.5 \mathrm{~cm}^{3}$. The temperature control maintained the samples at $75^{\circ} \mathrm{C}$ until the time of analysis (Mitterer-Daltoe et al., 2012). The samples were presented in plastic cups identified with a three-digit code and delivered monadically.

The assessors filled a 9-point hedonic scale pointing the overall acceptability of the burgers (where $9=$ like extremely, 5 = indifferent; 0 = disliked extremely). All the assessors that rejected the fresh sample, and those with inconsistent answers, were excluded from the statistics (Hough \& Fiszman, 2005). The Survival Function $\left(\mathrm{IBM}^{\circledR}\right.$ SPSS $\left.^{\circledR}\right)$ defined the end of the shelf life using the actuarial approach and the results of overall acceptability from the burgers.

\section{Cut-off point (COP)}

A previously trained panel (Marques et al., 2017) of 7 assessors and evaluated the rancid flavor. The score form had a $10 \mathrm{~cm}$ unstructured scale to distribute the samples within this range, anchored in "no rancid flavor" and "pronounced rancid flavor".

From the level of rancidity indicated by the trained panel and the overall acceptability of the samples given by the assessors, the value where the acceptability of the product began to significantly decrease was calculated trough Equation 1 (Garitta et al., 2015; Hough \& Fiszman, 2005):

$S=F-Z_{\alpha} \sqrt{\frac{2 * M S E}{n}}$

Where:

$S=$ Value where the acceptability of the product began to significantly decrease;

$\mathrm{F}=$ Fresh sample acceptability (mean from assessors);

$\mathrm{Z}_{5 \%}=$ Normal coordinated curve $(5 \%=2.58)$;

MSE = Mean square error obtained from the results of the consumer versus sample;

$\mathrm{n}=$ Number of assessors.

Using the proposed $S$ value, a graph displayed the results of the assessors (overall acceptability) versus those of the trained panel (rancidity intensity). From this graph, and replacing the value for $\mathrm{S}$ in the equation, the $\mathrm{X}$ acquired was the value of the maximum acceptable rancidity. Examining the results of the trained panel versus the days of storage was possible to find the exact COP, which represented the end of the shelf life.

\subsection{Microbiology of samples}

The microbiology analyses were done in the 30-day raw burger, in the Laboratory of Agroindustrial Quality (LAQUA) according to (Silva et al., 2007), where the plate count was used for Salmonella and Staphylococcus and the most probable number (MPN) for Coliforms.

\subsection{Physicochemical analyses}

The $\mathrm{pH}$ of the burgers was measured by homogenizing $25 \mathrm{~g}$ of burger with $5 \mathrm{ml}$ of water and using a bench top equipment $\left(\mathrm{TECNAL}^{\circledR}\right)$, with the sensor coupled to a digital meter. The thiobarbituric acid reactive substances (TBARS) were determined according to (Association of Official Analytical Chemistry, 2000). The calculation was based on a standard curve prepared with malonaldehyde. The chemical standard applied for the curve was 99\% 1,1,3,3-Tetramethoxypropane, Sigma-Aldrich ${ }^{\circledast}$.

\subsection{Statistical analysis}

All experiments were executed independently ( $\mathrm{n}=7$ for rancid flavor; $\mathrm{n}=6$ for $\mathrm{pH}$ and TBARS) and data expressed as mean \pm standard deviation. The software Statistica ${ }^{\circledR} 12.7$ performed the linear and exponential models, the one-way analysis of variance - ANOVA $(\mathrm{p}<0.05)$, the data distribution in the Shapiro Wilk (SW) and Levene tests, in addition to the COP graphs. The IBM ${ }^{\circledR}$ SPSS $^{\circledast} 20.0$ (IBM Company, 2010) investigated the survival analysis through Survival Function $(\mathrm{t}=$ time of storage), applying 10 intervals of three days (risk level $\alpha=5 \%$ ) and 50\% of rejection to establish the end of the shelf life.

\section{Results and discussion}

Shapiro Wilk test indicated that means were normally distributed, and thus the parameters were analyzed using a one-way analysis of variance (ANOVA; $p<0.05$ ). Levene test signaled the homocedasticity of the data, and without control sample, the Tukey test was conducted $(\mathrm{p}<0.05)$ in the parameters required.

\subsection{Microbiology}

After 30 days of refrigerated storage, the microbiological viability approved the burgers for consumption and sensory evaluation, following current legislation (Brasil, 2001). The grass carp burger presented $<10$ colony-forming unit $\left(\mathrm{CFU} . \mathrm{g}^{-1}\right)$ for coagulase-positive Staphylococci, the total absence of Salmonella sp., 3.6 MPN.mL ${ }^{-1}$ for total Coliforms and $<3.0 \mathrm{MPN} \cdot \mathrm{mL}^{-1}$ for thermotolerant microorganisms.

\subsection{Survival analysis}

Of the 80 initial consumers 23 rejected the fresh sample or presented inconsistent answers, remaining 57 for the treatment of the results. By means of Survival Function (Figure 2) and life table (Table 1), it was found a survival time of 21.29 days, a range of time where half of the assessors did not reject the fish burgers samples. Within the interval 21-24 days the probability to accept the samples is $29 \%$.

The time of 21.29 days is in agreement with the work developed by (Del Nobile et al., 2009) which found 22-23 days to the shelf life of fresh blue fish burger. (Vanitha et al., 2015) established that catla (carp) fish burgers were acceptable up to 15 days, microbiologically and accessing the sensory overall acceptability. 
Table 1. Survival analysis results of fish burgers stored for 30 days under refrigeration.

\begin{tabular}{cccccc}
\hline Interval Start Time & $\begin{array}{c}\text { Number Withdrawing } \\
\text { during Interval }\end{array}$ & Censored & $\begin{array}{c}\text { Number Exposed to } \\
\text { Risk }\end{array}$ & Proportion Surviving & Proportion Surviving \\
\hline $0-3$ & 456 & 0 & 456 & 0.88 & 0.88 \\
$3-6$ & 399 & 0 & 399 & 397 & 0.80 \\
$6-9$ & 399 & 3 & 342 & 1.00 & 0.76 \\
$9-12$ & 342 & 0 & 340 & 0.84 & 0.76 \\
$12-15$ & 342 & 4 & 282 & 1.00 & 0.64 \\
$15-18$ & 285 & 6 & 228 & 0.55 & 0.52 \\
$18-21$ & 228 & 0 & 220 & 0.58 & 0.29 \\
$21-24$ & 228 & 16 & 108 & 0.17 \\
$24-27$ & 114 & 11 & 57 & 1.00 & 0.17 \\
\hline
\end{tabular}

Survival results; 10 intervals of 3 days; End of shelf-life $=21.29$ days, interval 21-24.

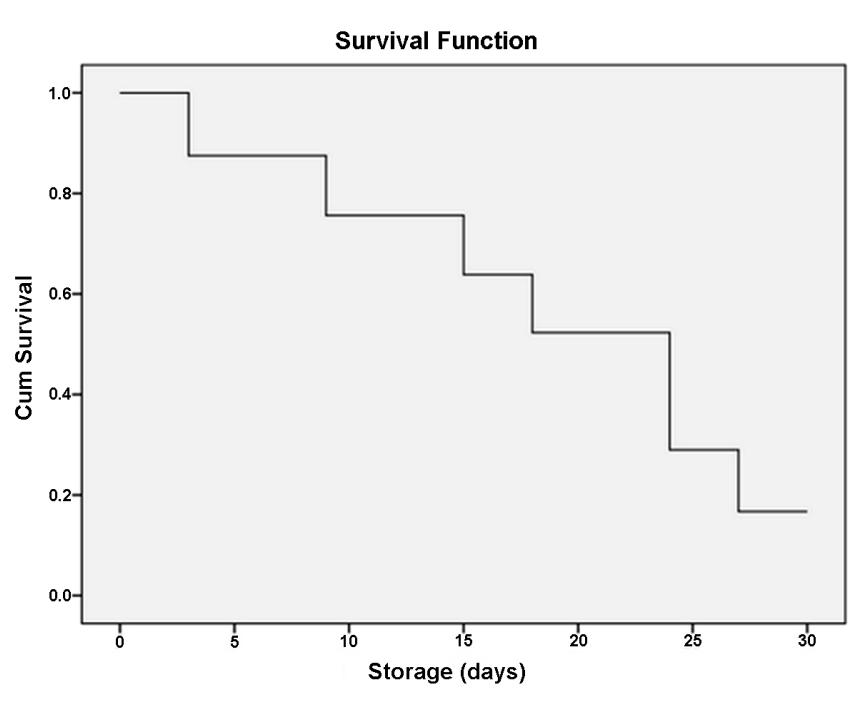

Figure 2. Survival analysis curve of fish burgers stored for 30 days under refrigeration.

It is possible to notice the accentuated decrease of probability from intervals 18-21 (52\%) and 21-24 (29\%). Figure 2 exhibits the sharpest drop in this range, where the horizontal axis shows the time to the event (end of shelf life) and the vertical axis shows the probability of survival. The Survival Funtion ( $t$ ) displayed the cumulative Survival Function on a linear scale, stating clearly the reductions of acceptability.

The life table as a descriptive procedure for examining the distribution of time-to-event variables allowed the authors to compare the distribution by levels. It subdivided the period of storage into smaller time intervals and then calculated the probabilities from each of the intervals, certifying the precise final interval.

It is promising to use this tool to determine survival time aiming at the end of the shelf life of a food product. The overall acceptability was an efficient descriptor to feed data in the software. The number of sensory assessors gave enough input to calculate a group pattern and provide a reasonable result.
Table 2. Values (mean \pm standard deviation) obtained for the rancid flavor, TBARS and $\mathrm{pH}$ of the burger samples.

\begin{tabular}{cccc}
\hline Sample & Rancid flavor $(\mathrm{cm})$ & TBARS mg.malo.kg & $\mathrm{pH}$ \\
\hline $\mathrm{H} 1-$ initial & $0.00^{\mathrm{e}} \pm 0.00$ & $0.34^{\mathrm{e}} \pm 0.06$ & $5.76^{\mathrm{e}} \pm 0.03$ \\
$\mathrm{H} 2-7$ days & $0.16^{\mathrm{e}} \pm 0.30$ & $0.65^{\mathrm{c}} \pm 0.07$ & $6.36^{\mathrm{c}} \pm 0.03$ \\
$\mathrm{H} 3-14$ days & $0.76^{\mathrm{de}} \pm 0.62$ & $0.72^{\mathrm{cd}} \pm 0.11$ & $6.10^{\mathrm{d}} \pm 0.05$ \\
$\mathrm{H} 4-17$ days & $1.54^{\mathrm{de}} \pm 1.03$ & $0.81^{\mathrm{bd}} \pm 0.04$ & $6.36^{\mathrm{c}} \pm 0.06$ \\
$\mathrm{H} 5$ - 21 days & $2.30^{\text {cde }} \pm 1.46$ & $0.88^{\mathrm{ab}} \pm 0.10$ & $6.95^{\mathrm{a}} \pm 0.15$ \\
$\mathrm{H} 6-23$ days & $3.31^{\mathrm{bcd}} \pm 2.02$ & $0.92^{\mathrm{ab}} \pm 0.09$ & $6.73^{\mathrm{b}} \pm 0.15$ \\
$\mathrm{H} 7-25$ days & $4.77^{\mathrm{abc}} \pm 2.60$ & $0.98^{\mathrm{a}} \pm 0.08$ & $6.91^{\mathrm{a}} \pm 0.05$ \\
$\mathrm{H} 8-30$ days & $5.97^{\mathrm{a}} \pm 2.67$ & $1.02^{\mathrm{a}} \pm 0.10$ & $6.14^{\mathrm{d}} \pm 0.06$ \\
\hline The same letters in the same column show that the means do not differ significantly; \\
(Tukey $p<0.05 ; \mathrm{n}=7$ for rancid flavor and $\mathrm{n}=6$ for $\mathrm{pH}$ and TBARS). malo $=$ malonaldehyde.
\end{tabular}

The positive $\mathrm{pH}$ peak on the $21^{\text {st }}$ day of storage (6.95) corroborates survival results (Table 2). The increase in $\mathrm{pH}$ is highly linked with the loss of meat quality, since it indicates the lack of freshness (Furlan et al., 2009). Furthermore it affects technological properties, and it is one of the most evaluated parameters in meats (Andrés et al., 2008). These changes of $\mathrm{pH}$ are explained by the literature as a result of the psychotropic bacteria metabolism (Genç et al., 2013; Křížek et al., 2004; Selgas et al., 2009).

\subsection{COP}

The $S$ value was calculated by means of the failure criterion, using the acceptability of the fresh sample (7.367), the mean square error $(0.748)$ and $n=57$ assessors. Thus the value where the acceptability of the product began to decrease was the point where the first significant difference in acceptability was found (Giménez et al., 2012, 2007). Replacing the values in Equation 2:

$S=7.367-\left(2.58_{5 \%}\right) * \sqrt{\frac{2 * 0.748}{57}}$

The value for $S$ with $5 \%$ significance was 6.95 . The corresponding rancid flavor $(\mathrm{cm})$ is $1.56 \mathrm{~cm}$ (Figure 3). Figure 4 shows that for $5 \%$ significance the COP was $17.06 \pm 1.0$, lower values when compared to those found with the survival analysis with $50 \%$ of rejection, of around 21 days. 


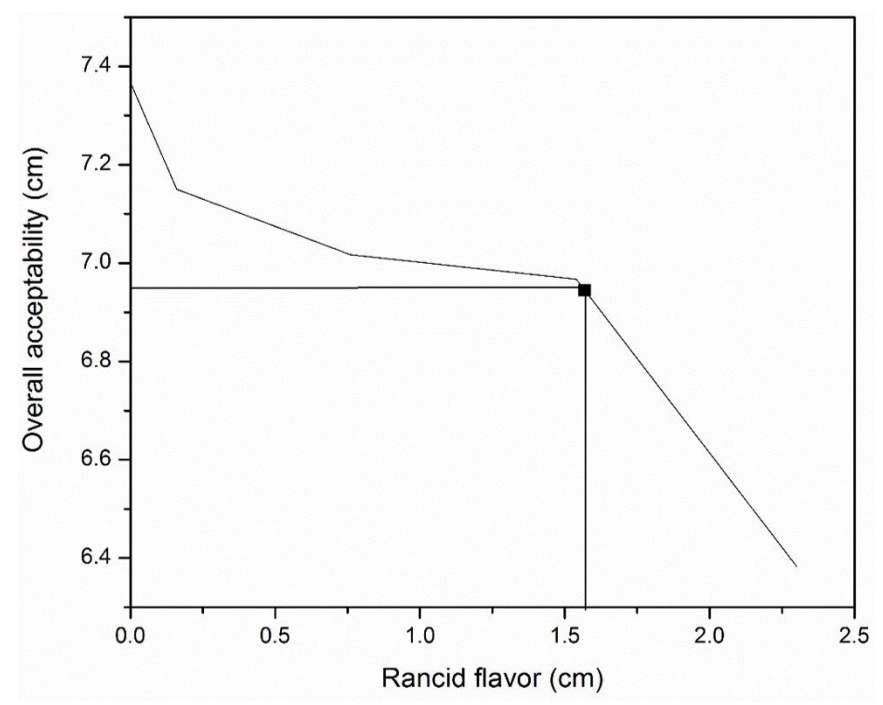

Figure 3. First step of the COP calculation. $S=6.949$; rancid flavor $=1.564 ; \mathrm{Z}(5 \%)=2.58$.

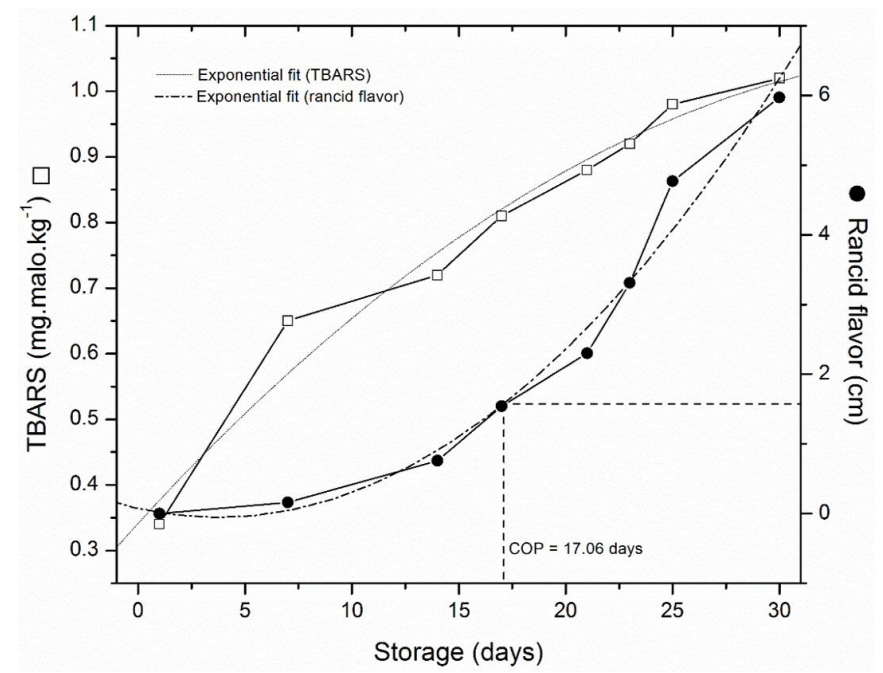

Figure 4. Exponential fits of TBARS (mg.malo.kg $\left.{ }^{-1}\right) \mathrm{R}^{2}=0.98$; and rancid flavor $(\mathrm{cm}) \mathrm{R}^{2}=0.99$. Moreover, the second step of the COP calculation.

Furthermore, it should be noted that the COP methodology often finds lower values than survival analysis for shelf life, because it is the value where the acceptability begins to decrease. (Giménez et al., 2007) found values of 1 to 5 days for the shelf life of bread formulations and considered that the method did not apply to the product analyzed.

It is important to perceive the acceptability profile decrease with storage time, showing a consistence with literature (Cruz et al., 2010; Garitta et al., 2015). Comi et al. (2015) found 12 days for commercial beef burgers. Selgas et al. (2009) analyzed refrigerated beef burgers for 17 days, with and without irradiation and addition of lycopene. The product showed to be microbiologically acceptable throughout the period as stated by (Vanitha et al., 2015) for the carp burger. In the three studies mentioned, storage was carried out in high gas barrier packages, with sealing and refrigeration under modified atmospheres, as the present study.

Moreover (Yu et al., 2017) reported the shelf life of grass carp as less than 11 days microbiologically, with off-odors perceived at the $7^{\text {th }}$ day, when raw, refrigerated and unpacked. The grass carp converted in burgers extended its shelf life, as showed the results from the present study. Then, in a comparison with (Yu et al., 2017) results, the vacuum packing combined with low temperature and food processing may prolong the shelf life at least 10 days concerning the sensory evaluation and 20 days regarding the microbiology permissible limit. In addition to that, relating other parameters, the $\mathrm{pH}$ increasing profile is similar and they found higher TBARS values at the same day of sampling (1.0 mg.malo. $\mathrm{kg}^{-1}$ - contrasting with $0.88 \mathrm{mg}$.malo. $\mathrm{kg}^{-1}$ from the present results around day 20 of the refrigerated storage). This fact confirms the importance of packing and food processing slowing the lipid oxidation.

The significant difference found for rancid flavor connected to the increase of rejection sustains the rancid flavor as a sensory critical descriptor. The consumption limit decrease, 21 to 17 days, seems to be slightly conservative but it is important to highlight the fact that the fish burgers are not a product established in the market yet, it is considered a new product, so this result is adequate (Hough, 2010) for the COP method.

\subsection{Rancidity and TBARS profiles}

Regarding the rancid flavor, the exponential fit represented the data better (Figure 4) with a value for $\mathrm{R}^{2}$ of $99 \%$ (Equation 3); the linear fit (Equation 4) had a correlation coefficient of $94 \%$, with values of $a=-0.40$ and $b=0.11$. Moreover, rancidity followed TBARS data (Table 1) with similar growth, which characterized a $\mathrm{R}^{2}$ of $98 \%(\mathrm{r}=0.99)$ with exponential fit. Both parameters had strong correlation, presenting similar Pearson correlation coefficients (0.99). This result reinforces their ability to evaluate the lipid oxidation of the fish burgers.

$$
\begin{aligned}
& F(t)=-0.31+0.24 \times e^{\frac{x}{8.76}} \quad R^{2}=0.99 \quad r=0.99 \\
& F(t)=-0.40+0.11 x \quad R^{2}=0.94 r=0.97
\end{aligned}
$$

\section{Conclusions}

The survival analysis and the $\mathrm{COP}$ were efficient in evaluating and estimating the shelf life of the grass carp burgers analyzed during 30 days under refrigeration. The survival analysis determined the end of the shelf life of the grass carp burgers after 21 days, with the COP indicating 17 days.

Both methodologies determined that the shelf life of the product exceed half the storage time tested, what confirms an important result for the applicability of this product on the market and schools. 21 days, even 17, is a good range time for consumption considering a refrigerated meat based product.

The fact that $\mathrm{COP}$ measures the $S$ value, where acceptability begins to decrease, must be highlighted. COP results showed a 
more conservative end for the shelf life although it is important to do not diminish its result since it applies straightforward graphical methods and uncomplicated calculations. Rancidity and TBARS are different parameters assessing the same descriptor in the fish burgers, the rancid flavor, and showed strong correlation, with high and comparable Pearson coefficients (0.99).

\section{Acknowledgements}

The National Council for Scientific and Technological Development - CNPq - Brazil supported this work (Universal Process grant numbers $n^{\circ} 456102 / 2014-0$ ). The authors also thank CAPES, the Postgraduate Program in Chemical and Biochemical Process Technology (PPGTP), acknowledgements for the technical support provided.

\section{References}

Andrés, S., Silva, A., Soares-Pereira, A. L., Martins, C., Bruno-Soares, A. M., \& Murray, I. (2008). The use of visible and near infrared reflectance spectroscopy to predict beef $\mathrm{M}$. longissimus thoracis et lumborum quality attributes. Meat Science, 78(3), 217-224. http:// dx.doi.org/10.1016/j.meatsci.2007.06.019. PMid:22062273.

Association of Official Analytical Chemistry - AOAC. (2000). Official methods of analysis (17th ed.). Washington: AOAC.

Belusso, A. C., Nogueira, B. A., Breda, L. S., \& Mitterer-Daltoé, M. L. (2016). Check all that apply (CATA) as an instrument for the development of fish products. Food Science and Technology (Campinas), 36(2), 1-7. http://dx.doi.org/10.1590/1678-457X.0026.

Brasil, Agência Nacional de Vigilância Sanitária. (2001, January 2). Aprova o Regulamento Técnico sobre padrões microbiológicos para alimentos (RDC no 12 de 2 de janeiro de 2001). Diário Oficial [da] República Federativa do Brasil.

Breda, L. S., Belusso, A. C., Nogueira, B. A., Camargo, G. H., \& Mitterer-Daltoé, M. L. (2017). Acceptance of fish hamburgers in school meals in the Southwest Region of Paraná, Brazil. Food Science and Technology (Campinas), 37(Suppl 1), 94-100. http://dx.doi. org/10.1590/1678-457x.34016.

Cai, L., Wu, X., Li, X., Zhong, K., Li, Y., \& Li, J. (2014). Effects of different freezing treatments on physicochemical responses and microbial characteristics of Japanese sea bass (Lateolabrax japonicas) fillets during refrigerated storage. Lebensmittel-Wissenschaft + Technologie, 59(1), 122-129. http://dx.doi.org/10.1016/j.lwt.2014.04.062.

Comi, G., Tirloni, E., Andyanto, D., Manzano, M., \& Iacumin, L. (2015). Use of bio-protective cultures to improve the shelf-life and the sensorial characteristics of commercial hamburgers. Lebensmittel-Wissenschaft + Technologie, 62(2), 1198-1202. http:// dx.doi.org/10.1016/j.lwt.2015.02.022.

Cruz, A. G., Walter, E. H. M., Cadena, R. S., Faria, J. A. F., Bolini, H. M. A., Pinheiro, H. P., \& Sant'Ana, A. S. (2010). Survival analysis methodology to predict the shelf-life of probiotic flavored yogurt. Food Research International, 43(5), 1444-1448. http://dx.doi. org/10.1016/j.foodres.2010.04.028.

Del Nobile, M. A., Corbo, M. R., Speranza, B., Sinigaglia, M., Conte, A., \& Caroprese, M. (2009). Combined effect of MAP and active compounds on fresh blue fish burger. International Journal of Food Microbiology, 135(3), 281-287. http://dx.doi.org/10.1016/j. ijfoodmicro.2009.07.024. PMid:19755204.
Donadini, G., Fumi, M., \& Porretta, S. (2013). Hedonic response to fish in preschoolers. Journal of Sensory Studies, 28(4), 282-296. http:// dx.doi.org/10.1111/joss.12043.

Esmerino, E. A., Paixão, J. A., Cruz, A. G., Garitta, L., Hough, G., \& Bolini, H. M. A. (2015). Survival analysis: a consumer-friendly method to estimate the optimum sucrose level in probiotic petit suisse. Journal of Dairy Science, 98(11), 7544-7551. http://dx.doi. org/10.3168/jds.2015-9651. PMid:26387013.

Food and Agriculture Organization - FAO. (2016). The state of world fisheries and aquaculture 2016. Geneva: FAO.

Fogaça, F. H. S., \& Sant'Ana, L. S. (2007). Tocopherol in the lipid stability of tilapia (Oreochromis niloticus) hamburgers. Food Chemistry, 105(3), 1214-1218. http://dx.doi.org/10.1016/j.foodchem.2007.02.032.

Furlan, V. J. M., Silva, A. P. R., \& Queiroz, M. I. (2009). Avaliação da eficiência de extração de compostos nitrogenados da polpa de anchoíta (Engraulis anchoita). Food Science and Technology (Campinas), 29(4), 834-839. http://dx.doi.org/10.1590/S0101-20612009000400021.

Garitta, L., Langohr, K., Elizagoyen, E., Gugole, F., Gómez, G., \& Hough, G. (2018). Survival analysis model to estimate sensory shelf life with temperature and illumination as accelerating factors. Food Quality and Preference, 68, 371-376. https://doi.org/10.1016/j. foodqual.2018.03.014.

Garitta, L., Langohr, K., Gómez, G., Hough, G., \& Beeren, C. (2015). Sensory cut-off point obtained from survival analysis statistics. Food Quality and Preference, 43, 135-140. http://dx.doi.org/10.1016/j. foodqual.2015.02.012.

Genç, I. Y., Esteves, E., Aníbal, J., \& Diler, A. (2013). Effects of chilled storage on quality of vacuum packed meagre fillets. Journal of Food Engineering, 115(4), 486-494. http://dx.doi.org/10.1016/j. jfoodeng.2012.09.007.

Giménez, A., Ares, F., \& Ares, G. (2012). Sensory shelf-life estimation: a review of current methodological approaches. Food Research International, 49(1), 311-325. http://dx.doi.org/10.1016/j.foodres.2012.07.008.

Giménez, A., \& Ares, G. (2019). Sensory shelf life estimation. In: C. M. Galanakis (Eds.), Food quality and shelf life. USA: Elsevier Inc. https://doi.org/10.1016/B978-0-12-817190-5.00011-2.

Giménez, A., Varela, P., Salvador, A., Ares, G., Fiszman, S., \& Garitta, L. (2007). Shelf life estimation of brown pan bread: a consumer approach. Food Quality and Preference, 18(2), 196-204. http://dx.doi. org/10.1016/j.foodqual.2005.09.017.

Horita, C. N., Esmerino, E. A., Vidal, V. A. S., Farah, J. S., Amaral, G. V., Bolini, H. M. A., Cruz, A. G., \& Pollonio, M. A. R. (2017). Sensory profiling of low sodium frankfurter containing garlic products: adequacy of polarized projective mapping compared with trained panel. Meat Science, 131, 90-98. http://dx.doi.org/10.1016/j. meatsci.2017.05.002. PMid:28500963.

Hough, G. (2010). Sensory shelf life estimation of food products. Boca Raton: CRC Press. http://dx.doi.org/10.1201/9781420092943.

Hough, G., \& Fiszman, S. (2005). Estimación de la vida útil sensorial de los alimentos. Valencia: Martín Impresores.

IBM Company. (2010). IBM ${ }^{\circledR}$ SPSS ${ }^{\circledR}$ Statistic for Windows ${ }^{\circledR}$. New York: IBM Company.

Kř́ižek, M., Vácha, F., Vorlová, L., Lukášová, J., \& Cupáková, Š. (2004). Biogenic amines in vacuum-packed and non-vacuum-packed flesh of carp (Cyprinus carpio) stored at different temperatures. Food Chemistry, 88(2), 185-191. http://dx.doi.org/10.1016/j.foodchem.2003.12.040.

Latorres, J. M., Mitterer-Daltoé, M. L., \& Queiroz, M. I. (2016). Hedonic and word association techniques confirm a successful way of introducing fish into public school meals. Journal of Sensory Studies, 31(3), https://doi.org/10.1111/joss.12204. 
Marques, C., Reis, A. S., Silva, L. D., Carpes, S. T., \& Mitterer-Daltoé, M. L. (2017). Selecting and training a panel to evaluate the rancid defect in soybean oil and fish hamburgers. Grasas y Aceites, 68(3), 203. http://dx.doi.org/10.3989/gya.0107171.

Marques, C., Lise, C., Bonadimann, F., \& Mitterer-Daltoe, M. L. (2019). Flash Profile as an effective method for assessment of odor profile in three different fishes. Journal of Food Science and Technology, 56(9), 4036-4044. http://dx.doi.org/10.1007/s13197-019-03872-w. PMid:31477975.

Mitterer Daltoé, M. L., Breda, L. S., Belusso, A. C., Nogueira, B. A., Rodrigues, D. P., Fiszman, S., \& Varela, P. (2017). Projective mapping with food stickers: a good tool for better understanding perception of fish in children of different ages. Food Quality and Preference, 57, 87-96. http://dx.doi.org/10.1016/j.foodqual.2016.12.003.

Mitterer-Daltoé, M. L., Latorres, J. M., Carbonera, N., Pastous-Madureira, L. S., \& Queiroz, M. I. (2012). Potencial de inserção de empanados de pescado na merenda escolar mediante determinantes individuais. Ciência Rural, 42(11), 2092-2098. http://dx.doi.org/10.1590/S010384782012001100029.

Raisi, M., Ghorbani, M., Sadeghi Mahoonak, A., Kashaninejad, M., \& Hosseini, H. (2015). Effect of storage atmosphere and temperature on the oxidative stability of almond kernels during long term storage. Journal of Stored Products Research, 62, 16-21. http://dx.doi. org/10.1016/j.jspr.2015.03.004.

Santos, B. A., Campagnol, P. C. B., Cruz, A. G., Galvão, M. T. E. L., Monteiro, R. A., Wagner, R., \& Pollonio, M. A. R. (2015). Check all that apply and free listing to describe the sensory characteristics of low sodium dry fermented sausages : Comparison with trained panel. Food Research International, 76(Pt 3), 725-734. http://dx.doi. org/10.1016/j.foodres.2015.06.035. PMid:28455058.
Selgas, M. D., García, M. L., \& Calvo, M. M. (2009). Effects of irradiation and storage on the physico-chemical and sensory properties of hamburgers enriched with lycopene. International Journal of Food Science \& Technology, 44(10), 1983-1989. http://dx.doi.org/10.1111/ j.1365-2621.2009.02017.x.

Silva, N., Okazaki, M. M., Junqueira, V. C. A., Silveira, N. F. A., Taniwaki, M. H., Santos, R. F. S., \& Gomes, R. A. R. (2007). Manual de métodos de análise microbiológica de alimentos (3. ed.). São Paulo: Livraria Varela.

Sveinsdóttir, K., Martinsdóttir, E., Thórsdóttir, F., Schelvis, R., Kole, A., \& Thórsdóttir, I. (2010). Evaluation of farmed cod products by a trained sensory panel and consumers in different test settings. Journal of Sensory Studies, 25(2), 280-293. http://dx.doi.org/10.1111/j.1745459X.2009.00257.x.

Tokur, B., Ozkütük, S., Atici, E., Ozyurt, G., \& Ozyurt, C. E. (2006). Chemical and sensory quality changes of fish fingers, made from mirror carp (Cyprinus carpio L., 1758), during frozen storage $\left(-18^{\circ} \mathrm{C}\right)$. Food Chemistry, 99(2), 335-341. http://dx.doi.org/10.1016/j. foodchem.2005.07.044.

Vanitha, M., Dhanapal, K., \& Vidya Sagar Reddy, G. (2015). Quality changes in fish burger from Catla (Catla Catla) during refrigerated storage. Journal of Food Science and Technology, 52(3), 1766-1771. http://dx.doi.org/10.1007/s13197-013-1161-1. PMid:25745254.

Yu, D., Jiang, Q., Xu, Y., \& Xia, W. (2017). The shelf life extension of refrigerated grass carp (Ctenopharyngodon idellus) fillets by chitosan coating combined with glycerol monolaurate. International Journal of Biological Macromolecules, 101, 448-454. http://dx.doi. org/10.1016/j.ijbiomac.2017.03.038. PMid:28283457. 